Running head: CONSUMER ETHNOCENTRISM AS A MODERATOR IN THE RELATIONSHIP BETWEEN OSTRACISM AND SELF-ESTEEM

Consumer Ethnocentrism as a Moderator in the Relationship Between

Ostracism and Self-esteem: Evidence From a Large Scale Survey

Sizhe Zhou

Guangdong Experimental High School

Email: sizhezhou.simon@gmail.com 


\begin{abstract}
When and why self-esteem drops down after an ostracism experience are worthy questions to answer in the field of ostracism. Considering the growing national pride in China, the current study investigates whether consumer ethnocentrism, a personality trait highly correlated with national pride in the consumer market, moderates the effects of ostracism on self-esteem through a large-scale survey $(\mathrm{n}=$ 1200). Confirmative factor analyses and moderation regression analyses are conducted to test the hypothesis. The results show that: 1 . Consistent with previous studies, ostracism negatively correlates with self-esteem. 2. Consumer ethnocentrism positively moderates ostracism's effects on self-esteem, such that individuals with high consumer ethnocentrism have a significant drop in self-esteem after ostracism. Potential explanations of the moderating effect of consumer ethnocentrism, implications and limitations of the current study, and direction for further studies are discussed.
\end{abstract}

Keywords: ostracism, self-esteem, consumer ethnocentrism, moderating effect 


\section{Consumer Ethnocentrism as a Moderator in the Relationship Between}

\section{Ostracism and Self-esteem: Evidence From a Large Scale Survey}

When we are excluded or ignored by others, we are experiencing ostracism (Williams, 2009). Ostracism is a cross-cultural phenomenon that commonly happens in a school or a workplace when an individual or a group is excluded or ignored by other individuals or groups, which causes severe consequences and negative experiences (Williams \& Nida, 2011). These consequences are detrimental to not only individuals but also society, such that the ostracism is a potential precursor for school shootings (Williams, 2007). A well-known framework to interpret ostracism is the temporal need-threat model, which purposes that individuals experience a threat to four needs: self-esteem, belongingness, control, and meaningful existence after ostracism (Williams, 2009). Based on this model, a considerable amount of study investigates the relationship between ostracism and self-esteem; these studies provide strong evidence that self-esteem is negatively correlated with ostracism (e.g. Fatima, Ilyas, Rehman, \& Imran, 2017; Howard, Cogswell, \& Smith, 2020; Wu, Wei, \& Hui, 2011).

The effect of ostracism on self-esteem varies by individual, according to their personality traits, which means that there are some potential moderators in this relationship. Bernstein et al. (2013) confirm that self-esteem across individuals is not equally affected by ostracism. Previous studies indicate that perceived ostracism is moderated by individual differences such as narcissism, attachment style, facial 
emotion recognition ability, and personality (Hou et al., 2019; Kong, 2016, as cited in Hou et al., 2019; Williams \& Govan, 2005; Wu et al., 2011).

Most of the aforementioned studies were conducted in a school or workplace context, but few of the them have specifically focused on the moderators in marketplace contexts, even though previous studies have emphasized the importance of ostracism in the marketplace (Mao, Liu, Jiang, \& Zhang, 2018; Mead, Baumeister, Stillman, Rawn, \& Vohs, 2011; Yang, 2019). A potential moderator directly correlated with the individual's consumer behavior is consumer ethnocentrism, which refers to the preference of the domestic product over foreign product (Shimp \& Sharma, 1987). Consumer ethnocentrism is correlated with one's national identity and shares similarities with other traits that moderate the relationship between ostracism and self-esteem.

This study investigates whether consumer ethnocentrism is a moderator in the relationship between ostracism and self-esteem, aiming to extend the interpretation of the internal mechanism of ostracism's influence on consumers' self-perception in the marketplace context. A large-scale survey, Ostracism Experience Scale for Adolescents (OES-A), Rosenberg self-esteem scale (RSE), and Consumer Ethnocentrism Extended measures scale (CEESCALE) are employed to measure an individual's level of ostracism experience, self-esteem, and consumer ethnocentrism, respectively. 


\section{Literature Review}

Previous studies have found that ostracism, the phenomena when an individual is excluded or ignored by others, threatens one's self-esteem (Williams, 2007). This influence of ostracism on self-esteem can be explained by the sociometer theory (Leary \& Baumeister, 2000), which suggests that self-esteem is determined by individuals' perception of their social acceptance of themselves and their relational value. Sociometer theory is well supported by previous studies (e.g. Anderson, 2019; Fatima et al., 2017; Smart Richman \& Leary, 2009; Wesselmann \& Williams, 2017). Therefore, the current study hypothesizes that ostracism is negatively correlated with self-esteem (Hypothesis 1).

Self-esteem is also correlated with some personality traits, and one of these traits that has direct impact on consumer behavior is consumer ethnocentrism. Consumer ethnocentric people prefer domestic products over foreign products, even when the products have lower quality (Shimp \& Sharma, 1987). Previous studies have found that consumer ethnocentrism is a personality trait formed in childhood and can hardly be changed by social factors (Hooghe, Reeskens, \& Stolle, 2007; as cited in, Siamagka \& Balabanis, 2015). Many studies (El Banna, Papadopoulos, Murphy, Rod, \& Rojas-Méndez, 2018; Hult, Keillor, \& Lafferty, 1999; Vida, Dmitrović, \& Obadia, 2008 , etc.) suggest that consumer ethnocentrism plays a significant role in national identity and ethnic identity. The national identity and ethnic identity of an individual correlates with one's self-esteem. Phinney (1991) suggests that when one aligns with their ethnic group's mainstream attitudes or beliefs, they have high self-esteem, 
whereas self-esteem will significantly drop down when it is not consistent. In other words, whether or not the consumer's attitudes toward foreign and domestic products are consistent with the mainstream attitude is correlated with their self-esteem. Since studies have found that the tendency is that the Chinese consumer increasingly supports domestic product (Jin, Shao, Griffin, \& Ross, 2018; Kwok, Uncles, \& Huang, 2006; Parker, Haytko, \& Hermans, 2011), it is therefore reasonable to infer consumer ethnocentrism is mainstream. Base on this belief, the current study hypothesizes that consumer ethnocentrism is positively correlated with self-esteem (Hypothesis 2).

Consumer ethnocentrism is the consumer-level ethnocentrism, and it shares similarities with general ethnocentrism, one's belief that the group or country they identify with is superior than others (Shimp \& Sharma, 1987). Studies have found that the ethnocentric individual is more likely to be influenced by social norms, and they are more likely to consider the social value of consumer behavior (Siamagka \& Balabanis, 2015), so it is reasonable to infer that the consumer ethnocentric individual is more sensitive and vulnerable to social influences and social exclusion. Also, Bizumic and Duckitt (2008) indicate that ethnocentrism embodies the group-level narcissism, and the strong relationship between narcissism and ethnocentrism is found. Since narcissistic individuals show they are more vulnerable and sensitive to threats, such as the threat to self-esteem (Wink, 1991), this study assumes that the ethnocentric individual will also be vulnerable and sensitive to threat.

Therefore, the current study hypothesizes that consumer ethnocentrism is a moderator in the effect of ostracism on self-esteem, such that the increase of one's 
level of consumer ethnocentrism will predict the more substantial effect of ostracism on self-esteem (Hypothesis 3).

The conceptual model is present in Figure 1.

\section{Method}

\section{Sample and Procedure}

A total of 1200 questionnaires were collected through the online platform Wenjuanxing. Participants are typical consumers from mainland China; 52.2\% participants are male $(n=627)$ and $47.7 \%$ participants are female $(n=573)$. As part of the research study, all participants completed three assessment tools: Ostracism Experience Scale for Adolescents (OES-A), Rosenberg self-esteem scale (RSE), and Consumer Ethnocentrism Extended measures scale (CEESCALE) to measure their level of ostracism experience, self-esteem, and consumer ethnocentrism respectively.

\section{Measures}

Ostracism. The Ostracism Experience Scale measures the ostracism for Adolescents (OES-A), a well-developed self-report measure for ostracism experience among adolescents (Gilman, Carter-Sowell, DeWall, Adams, \& Carboni, 2013). The scale was translated and adjusted to Chinese by Zhang, Huang, \& Dong (2018). It contains 11 items and consists of two dimensions (social exclusion and social ignored). Participants rate the items on a 5-point scale, from extremely not match (1) to incredible match (5), and a higher score means the participants faced a higher level of social exclusion. The adapted scale shows good validity and reliability in previous 
studies (e.g. Li, Zhao, \& Yu, 2019; Niu, Sun, Tian, Fan, \& Zhou, 2016; Zhang et al., 2018). The Cronbach's a of this scale in the current study is 0.939 .

Self-esteem. The self-esteem is measured by the Rosenberg self-esteem scale (RSE), a well-developed self-report measure for self-esteem developed by Rosenberg (1965). The scale consists of ten items, and participants rated them on a 5-point scale, from strongly disagree (1) to strongly agree (5). The Chinese version of RSE is developed for a long time and adjusts to adapt to the Chinese population, and strong validity and reliability are shown in previous studies (Cheng \& Hamid, 1995; Shen \& Cai, 2008; Wang et al., 2018). The Cronbach's a of this scale in the current study is 0.804 .

Consumer Ethnocentrism. Consumer Ethnocentrism is measured by the Consumer Ethnocentrism Extended measures scale (CEESCALE), developed by Siamagka and Balabanis (2015). This scale is developed from the Consumer Ethnocentrism Tendencies Scale (CETSCALE) developed by Shimp and Sharma (1987). It consists of 15 items, and participants rated them on a 7-point scale, from strongly disagree (1) to strongly agree (7). The scale shows good validity and reliability on Chinese participants in the previous study (Yii \& Hair, 2020). The Cronbach's a of this scale in the current study is 0.939 . 


\section{Results}

\section{Preliminary Analysis}

\section{Confirmative Factor Analyses (CFAs)}

The current study first conducts confirmative factor analyses to test the convergent and discriminant critical variables in this study. The initial factor loading is presented in Table 2. The current study uses the Tucker-Lewis Index (TLI, Tucker \& Lewis, 1973), the comparative fit index (CFI, Bentler, 1990), and the root mean square error of approximation (RMSEA, Browne, 1993) to assess the model fit. The initial fitness index is presented in Table 1. Since the Comparative Fit Index (CFI) is 0.868 , and Tucker-Lewis Index (TLI) is 0.859 , it means both of these two fitness indices do not achieve the required level, and therefore an item-deletion process is needed to improve model fitness.

The current study adopts the item-deletion procedure frequently used in previous studies (Awang, 2015); items with the least factor loading were removed one by one until fitness indexes are acceptable. Therefore, because items SE2, SE4 have the lowest factor loading, SE2 and SE4 are deleted. After deletion, the model fit of measurements is acceptable, and the fitness index is presented in Table $\mathbf{3}$.

\section{Descriptive Statistics}

Table 4 presents each variable's mean and standard deviation, and Table 5 presents the inter-correlation of each value. As shown on the table, ostracism is statistically significantly correlated with self-esteem $(r=-0.668, \mathrm{p}=0.00)$, and it also 
statistically significantly correlated with consumer ethnocentrism $(r=-0.107, \mathrm{p}=$

$0.00)$. Moreover, self-esteem is positively predicted by ostracism $(r=0.158, \mathrm{p}=0.00)$.

These results confirm both Hypothesis $\mathbf{1}$ and Hypothesis 2, which is that self-esteem is negatively predicted by ostracism and positively predicted by consumer ethnocentrism.

\section{Moderation Analysis}

The moderating effect of consumer ethnocentrism in the relationship between ostracism and self-esteem is analyzed using Model 1 in PROCESS V3.4.1 (Hayes, 2017). All the variables are standardized to avoid the multicollinearity phenomena in moderation analysis (Dunlap \& Kemery, 1987).

Then the regression model of the moderating effect is conducted, and the result is shown in Table 6. As shown in the table, the interaction effect between ostracism and consumer ethnocentrism is statistically significant $(\beta=-0.195, \mathrm{t}=$ $0.625, \mathrm{p}=0.000$ ), which implies the moderating effect is present.

To examine how consumer ethnocentrism moderates ostracism's effects on self-esteem, a simple slope analysis is conducted by selecting the plus and minus one standard deviation of the average value of consumer ethnocentrism. The result is presented in Table 7, and the graph of the interaction effect is presented in Figure 2. This result indicates that as an individual's level of consumer ethnocentrism increases, the effect of ostracism on self-esteem is increasing from low $(\beta=-1.02, \mathrm{t}=-19.7 \mathrm{p}=$ 
$0.000)$ to mean $(\beta=-1.21, \mathrm{t}=-31.8, \mathrm{p}=0.000)$ and to high $(\beta=-1.41, \mathrm{t}=--30.9, \mathrm{p}=$ 0.000). These results are consistent with Hypothesis 3.

\section{Discussion}

The current study investigates whether consumer ethnocentrism is a moderator of the effects of ostracism on self-esteem. Based on results, it shows that ostracism is negatively correlated with self-esteem, consistent with previous studies (e.g. Anderson, 2019; Fatima et al., 2017; Smart Richman \& Leary, 2009; Wesselmann \& Williams, 2017). Also, it confirms that self-esteem is positively predicted by consumer ethnocentrism, which confirms our Hypothesis 2, and it is consistent with previous studies, implying the potential prosocial nature and sense of belonging gained through consumer ethnocentrism (El Banna et al., 2018; Hult et al., 1999; Vida et al., 2008, etc.). Lastly, the result of this moderator analysis and simple slope analysis supports Hypothesis 3, which is that consumer ethnocentrism is a moderator of ostracism's effects on self-esteem. More specifically, the consumer with a higher level of consumer ethnocentrism will be more susceptible to ostracism, and therefore the consumer will present a great drop in self-esteem.

Aligning with previous studies (e.g. Baumeister et al., 2005; as cited in, Bernstein et al., 2013), the current study finds the effects of self-esteem are moderated by other variables. The role of consumer ethnocentrism as a moderator is probably the same as other individual differences, such as narcissism, attachment style, facial emotion recognition ability, and personality (Hou et al., 2019; Kong, 2016, as cited in Hou et al., 2019; Williams \& Govan, 2005; Wu et al., 2011), because the 
ethnocentrism shares the same characteristic, such stable, early formed, and insusceptible, with these variables.

The result of the current study can be interpreted through the need-threat model (Williams, 2007) and sociometer theory (Leary \& Baumeister, 2000), which suggests that the threat to belonging facilitates an individual to be more sensitive to social cues, which helps them gain success in further social interaction. Based on this theory, as we know, consumer ethnocentrism is a significant element in social identity. The drop in self-esteem can be interpreted as a response to the failure of social identity. Greitemeyer (2012) finds that ostracized individuals will show increasing ethnocentrism when socially accepted and a decrease when socially rejected. Although the potential explanation was given, there are no tested theories to explain the moderation effect's internal mechanism found in this study. Further study is needed to use the experimental method or time-lagged data to test this effect's internal mechanism.

The current study provides empirical evidence for consumer ethnocentrism's moderating effect on the relationship between ostracism and self-esteem. The current study provides a new perspective to understand the internal mechanism of the phenomena of self-esteem decline after ostracism. Consumer ethnocentrism is a common psychological trait in today's society. Understanding the effects of consumer ethnocentrism can improve the management and intervention of negative experiences of ostracism, especially in marketplace ostracism. 
Some limitations of the current study are noticed. First, the measurement of ostracism is not specialized in consumer behavior, but a general experience. In other words, the current moderation effect of consumer ethnocentrism is not on consumer or purchasing behavior, but one's experience. It is doubtable whether consumer ethnocentrism is relevant to one's ostracism experience in another event. A potential explanation is that for consumers, purchasing behavior is crucial in their daily life, and the attitudes toward the various products are a significant part of forming their social network. The ostracism may sometimes correlate with purchasing behavior, or the consumer might doubt whether their purchasing style causes the ostracism. This attribution leads to the effect. To avoid this problem, further study should try to build up a new psychometric questionnaire to precisely measure individual consumer ethnocentrism.

Also, the current study does not consider individuals' purchasing power and socioeconomic status. Nijssen and Douglas (2004) find that foreign and domestic product accessibility is a moderator in the effects of consumer ethnocentrism. Therefore, further study is needed to investigate the effects of incomes and purchasing power in the current result. 


\section{References}

Anderson, R. S. (2019). Self-Compassion Versus Self-Esteem for an Experience of Ostracism.

Awang, Z. (2015). SEM made simple: A gentle approach to learning Structural Equation Modeling. MPWS Rich Publication.

Baumeister, R. F., DeWall, C. N., Ciarocco, N. J., \& Twenge, J. M. (2005). Social exclusion impairs self-regulation. Journal of personality and social psychology, 88(4), 589.

Bentler, P. M. (1990). Comparative fit indexes in structural models. Psychological bulletin, 107(2), 238.

Bernstein, M. J., Claypool, H. M., Young, S. G., Tuscherer, T., Sacco, D. F., \& Brown, C. M. (2013). Never let them see you cry: Self-presentation as a moderator of the relationship between exclusion and self-esteem. Personality and Social Psychology Bulletin, 39(10), 1293-1305.

Bizumic, B., \& Duckitt, J. (2008). "My group is not worthy of me": Narcissism and ethnocentrism. Political Psychology, 29(3), 437-453.

Blackhart, G. C., Nelson, B. C., Knowles, M. L., \& Baumeister, R. F. (2009). Rejection elicits emotional reactions but neither causes immediate distress nor lowers self-esteem: A meta-analytic review of 192 studies on social exclusion. Personality and Social Psychology Review, 13(4), 269-309. 
Browne, M. W. (1993). Alternative ways of assessing model fit. Testing structural equation models.

Cheng, S.-T., \& Hamid, P. N. (1995). An error in the use of translated scales: The Rosenberg Self-Esteem Scale for Chinese. Perceptual and Motor Skills, 81(2), $431-434$.

Dunlap, W. P., \& Kemery, E. R. (1987). Failure to detect moderating effects: Is multicollinearity the problem?

El Banna, A., Papadopoulos, N., Murphy, S. A., Rod, M., \& Rojas-Méndez, J. I. (2018). Ethnic identity, consumer ethnocentrism, and purchase intentions among bi-cultural ethnic consumers:"Divided loyalties" or "dual allegiance"? Journal of Business Research, 82, 310-319.

Fatima, T., Ilyas, M., Rehman, C. A., \& Imran, M. K. (2017). Empirical investigation of relationship between workplace ostracism and employee silence: A test of mediating effects of self-esteem and meaningful existence in context of public sector universities in Punjab. Abasyn Journal of Social Sciences, 10(1), 111-128.

Festinger, L. (1962). Cognitive dissonance. Scientific American, 207(4), 93-106.

Gilman, R., Carter-Sowell, A., DeWall, C. N., Adams, R. E., \& Carboni, I. (2013). Validation of the ostracism experience scale for adolescents. Psychological assessment, 25(2), 319 . 
Greitemeyer, T. (2012). Boosting one's social identity: Effects of social exclusion on ethnocentrism. Basic and applied social psychology, 34(5), 410-416.

Harmon-Jones, E. (2000). Cognitive dissonance and experienced negative affect: Evidence that dissonance increases experienced negative affect even in the absence of aversive consequences. Personality and Social Psychology Bulletin, 26(12), 1490-1501.

Hayes, A. F. (2017). Introduction to mediation, moderation, and conditional process analysis: A regression-based approach: Guilford publications.

Hooghe, M., Reeskens, T., \& Stolle, D. (2007). Diversity, multiculturalism and social cohesion: Trust and ethnocentrism in European societies. Paper presented at the Diversity and Canada's Future, Date: 2005/10/13-2005/10/15.

Hou, N., Fan, J., Tan, J., Stuhlman, M., Liu, C., \& Valdez, G. (2019). Understanding Ostracism from Attachment Perspective: Testing a Moderated Mediation Model. Journal of International Students, $9(3), 856-872$.

Howard, M. C., Cogswell, J. E., \& Smith, M. B. (2020). The antecedents and outcomes of workplace ostracism: A meta-analysis. Journal of Applied Psychology, 105(6), 577.

Hult, G. T. M., Keillor, B. D., \& Lafferty, B. A. (1999). A cross-national assessment of social desirability bias and consumer ethnocentrism. Journal of Global Marketing, 12(4), 29-43. 
Jin, T., Shao, W., Griffin, D., \& Ross, M. (2018). How young Chinese consumers view Chinese brands. Young Consumers.

Kong, D. T. (2016). Ostracism perception as a multiplicative function of trait self-esteem, mindfulness, and facial emotion recognition ability. Personality and Individual Differences, 93, 68-73.

Kwok, S., Uncles, M., \& Huang, Y. (2006). Brand preferences and brand choices among urban Chinese consumers. Asia Pacific Journal of Marketing and Logistics.

Leary, M. R., \& Baumeister, R. F. (2000). The nature and function of self-esteem: Sociometer theory. In Advances in experimental social psychology (Vol. 32, pp. 1-62): Elsevier.

Li, S., Zhao, F., \& Yu, G. (2019). Ostracism and aggression among adolescents: Implicit theories of personality moderated the mediating effect of self-esteem. Children and Youth Services Review, 100, 105-111.

Mao, Y., Liu, Y., Jiang, C., \& Zhang, I. D. (2018). Why am I ostracized and how would I react?-A review of workplace ostracism research. Asia Pacific Journal of Management, 35(3), 745-767.

Mead, N. L., Baumeister, R. F., Stillman, T. F., Rawn, C. D., \& Vohs, K. D. (2011). Social exclusion causes people to spend and consume strategically in the service of affiliation. Journal of Consumer Research, 37(5), 902-919. 
Nijssen, E. J., \& Douglas, S. P. (2004). Examining the animosity model in a country with a high level of foreign trade. International Journal of Research in Marketing, 21(1), 23-38.

Niu, G.-F., Sun, X.-J., Tian, Y., Fan, C.-Y., \& Zhou, Z.-K. (2016). Resilience moderates the relationship between ostracism and depression among Chinese adolescents. Personality and Individual Differences, 99, 77-80.

Parker, R. S., Haytko, D. L., \& Hermans, C. M. (2011). Ethnocentrism and its effect on the Chinese consumer: A threat to foreign goods? Journal of Global Marketing, 24(1), 4-17.

Phinney, J. S. (1991). Ethnic identity and self-esteem: A review and integration. Hispanic journal of behavioral sciences, 13(2), 193-208.

Rosenberg, M. (1965). Rosenberg self-esteem scale (RSE). Acceptance and commitment therapy. Measures package, 61(52), 18.

Shen, Z.-L., \& Cai, T.-S. (2008). Disposal to the 8th item of Rosenberg Self-Esteem Scale (Chinese version). Chinese Mental Health Journal.

Shimp, T. A., \& Sharma, S. (1987). Consumer ethnocentrism: Construction and validation of the CETSCALE. Journal of marketing research, 24(3), 280-289.

Siamagka, N.-T., \& Balabanis, G. (2015). Revisiting consumer ethnocentrism: review, reconceptualization, and empirical testing. Journal of International Marketing, 23(3), 66-86. 
Smart Richman, L., \& Leary, M. R. (2009). Reactions to discrimination, stigmatization, ostracism, and other forms of interpersonal rejection: a multimotive model. Psychological review, 116(2), 365.

Tucker, L. R., \& Lewis, C. (1973). A reliability coefficient for maximum likelihood factor analysis. Psychometrika, 38(1), 1-10.

Vida, I., Dmitrović, T., \& Obadia, C. (2008). The role of ethnic affiliation in consumer ethnocentrism. European journal of marketing.

Wang, X., Wang, W., Xie, X., Wang, P., Wang, Y., Nie, J., \& Lei, L. (2018). Self-esteem and depression among Chinese adults: A moderated mediation model of relationship satisfaction and positive affect. Personality and Individual Differences, 135, 121-127.

Wesselmann, E. D., \& Williams, K. D. (2017). Social life and social death: Inclusion, ostracism, and rejection in groups. Group Processes \& Intergroup Relations, 20(5), 693-706.

Williams, K. D. (2007). Ostracism. Annu. Rev. Psychol., 58, 425-452.

Williams, K. D. (2009). Ostracism: A temporal need - threat model. Advances in experimental social psychology, 41, 275-314.

Williams, K. D., \& Govan, C. L. (2005). Reacting to ostracism: Retaliation or reconciliation. The social psychology of inclusion and exclusion, 47-62.

Williams, K. D., \& Nida, S. A. (2011). Ostracism: Consequences and coping. Current 
Directions in Psychological Science, 20(2), 71-75.

Wink, P. (1991). Two faces of narcissism. Journal of personality and social psychology, 61(4), 590.

Wu, L., Wei, L., \& Hui, C. (2011). Dispositional antecedents and consequences of workplace ostracism: An empirical examination. Frontiers of Business Research in China, 5(1), 23-44.

Yang, X. (2019). A Literature Review of the Influence of Social Exclusion on Consumer Behavior and Prospects. American Journal of Industrial and Business Management, 9(3), 764-779.

Yii, H., \& Hair, M. (2020). The reciprocal effects of loneliness and consumer ethnocentrism in online behavior. Australasian Marketing Journal (AMJ), $28(1), 35-46$.

Zhang, D., Huang, L., \& Dong, Y. (2018). Reliability and validity of the ostracism experience scale for adolescents in Chinese adolescents. Chinese Journal of Clinical Psychology, 26(6), 1123-1126. 
Table 1

Factor Loading of Measurements

\begin{tabular}{|c|c|c|c|c|c|}
\hline Factor & Indicator & Estimate & SE & $\begin{array}{c}\text { Standardized } \mathrm{Z} \\
\text { Score }\end{array}$ & p \\
\hline \multirow[t]{10}{*}{ Self-esteem } & SE1 & 0.445 & 0.0273 & 16.3 & $<.001$ \\
\hline & SE2 & 0.311 & 0.0289 & 10.8 & $<.001$ \\
\hline & SE3 & 0.873 & 0.0302 & 28.9 & $<.001$ \\
\hline & SE4 & 0.336 & 0.0284 & 11.9 & $<.001$ \\
\hline & SE5 & 0.758 & 0.0300 & 25.3 & $<.001$ \\
\hline & SE6 & 0.335 & 0.0289 & 11.6 & $<.001$ \\
\hline & SE7 & 0.371 & 0.0294 & 12.6 & $<.001$ \\
\hline & SE8 & 0.531 & 0.0287 & 18.5 & $<.001$ \\
\hline & SE9 & 0.852 & 0.0310 & 27.5 & $<.001$ \\
\hline & SE10 & 0.861 & 0.0310 & 27.8 & $<.001$ \\
\hline \multirow[t]{9}{*}{ Ostracism } & OS1 & 0.843 & 0.0308 & 27.4 & $<.001$ \\
\hline & OS2 & 0.840 & 0.0274 & 30.6 & $<.001$ \\
\hline & OS3 & 0.894 & 0.0292 & 30.6 & $<.001$ \\
\hline & OS4 & 0.958 & 0.0294 & 32.6 & $<.001$ \\
\hline & OS5 & 0.887 & 0.0285 & 31.1 & $<.001$ \\
\hline & OS6 & 0.950 & 0.0298 & 31.8 & $<.001$ \\
\hline & OS7 & 0.938 & 0.0298 & 31.5 & $<.001$ \\
\hline & OS8 & 0.898 & 0.0290 & 30.9 & $<.001$ \\
\hline & Os9 & 0.937 & 0.0290 & 32.4 & $<.001$ \\
\hline
\end{tabular}




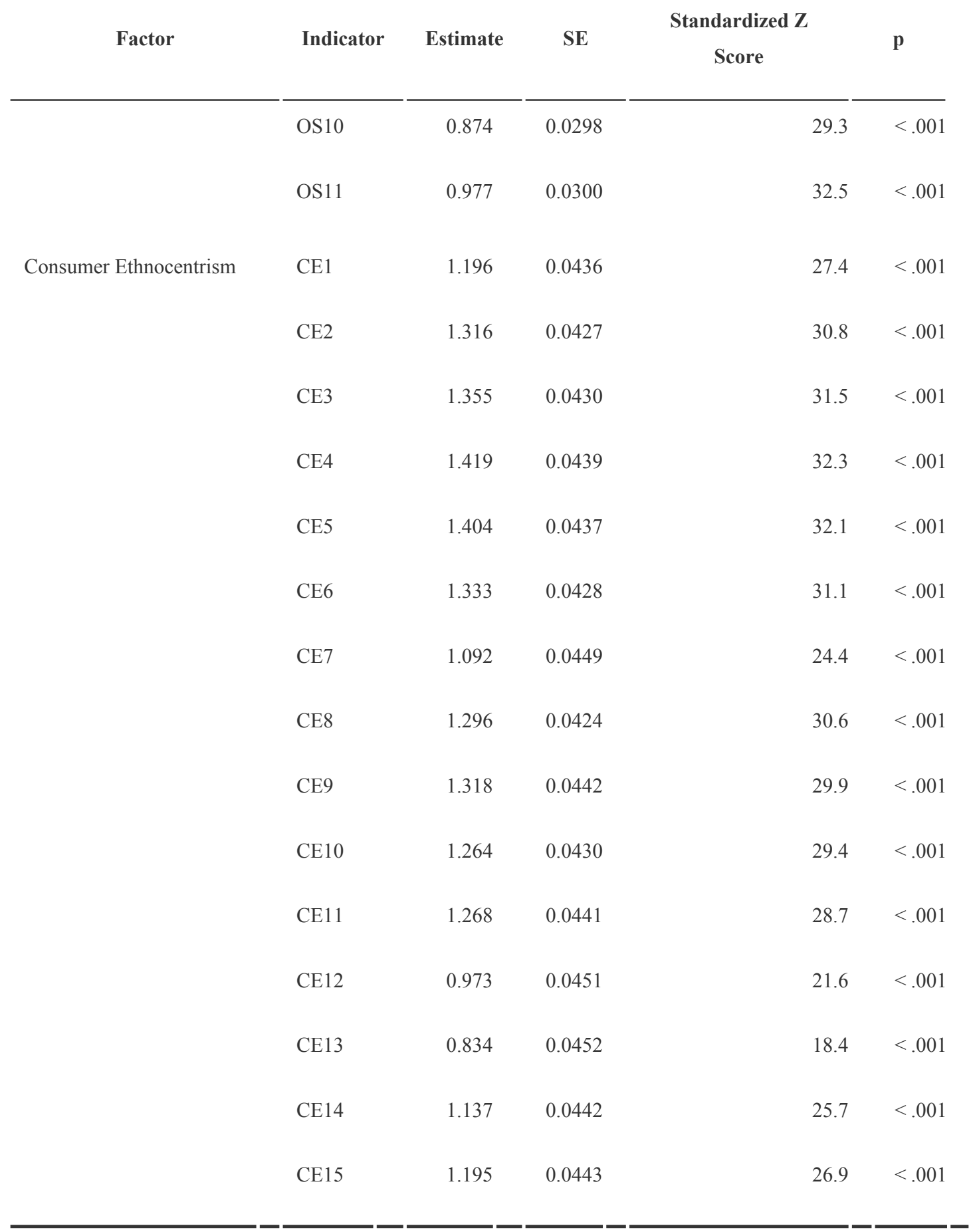

Note: Estimate refers to factor loading, the standard for an accepted value is factor loading $>0.6$ 


\section{Table 2}

Initial Fit Measures

RMSEA 90\% CI

\begin{tabular}{llccc} 
CFI & TLI RMSEA & Lower & Upper \\
0.868 & 0.859 & 0.0687 & 0.0667 & 0.0707 \\
\hline
\end{tabular}

Note: CFI is Comparative Fit Index, and the level of acceptance of it is CFI $>0.90$;

TLI is Tucker-Lewis Index, and the level of acceptance of it is TLI $>0.90$; RMSEA is Root Mean Square of Error Approximation, and the level of acceptance of it is RMSEA $<0.08$. 


\section{Table 3}

Fitness Measures After Item-deletion

\begin{tabular}{llccc}
\hline & & \multicolumn{2}{c}{ RMSEA 90\% CI } \\
\cline { 4 - 5 } CFI & TLI & RMSEA & Lower & Upper \\
\hline 0.917 & 0.911 & 0.0574 & 0.0522 & 0.0597 \\
\hline
\end{tabular}

Note: CFI is Comparative Fit Index, and the level of acceptance of it is CFI $>0.90$;

TLI is Tucker-Lewis Index, and the level of acceptance of it is TLI $>0.90$; RMSEA is Root Mean Square of Error Approximation, and the level of acceptance of it is RMSEA $<0.08$. 
Table 4

Mean and Standard Deviation

Self-esteem Consumer Ethnocentrism Ostracism

\begin{tabular}{lccc}
\hline Mean & 19.4 & 59.7 & 35.9 \\
Standard deviation & 4.07 & 12.0 & 10.3 \\
\hline
\end{tabular}

Note: $\mathrm{n}=1200$ 
Table 5

Correlation Matrix

Consumer
ethnocentrism

\begin{tabular}{lcc}
$\begin{array}{l}\text { Consumer } \\
\text { ethnocentrism }\end{array}$ & - \\
Self-esteem & $0.158^{* * *}$ & - \\
Ostracism & $-0.107^{* * *}$ & $-0.688^{* * *}$ \\
\hline
\end{tabular}

Note: $\mathrm{n}=1200 .{ }^{*} \mathrm{p}<.05,{ }^{* *} \mathrm{p}<.01,{ }^{* * *} \mathrm{p}<.001$ 


\section{Table 6}

Result for Moderation Analysis

\begin{tabular}{|c|c|c|c|c|c|}
\hline & \multirow[b]{2}{*}{$\beta$} & \multirow[b]{2}{*}{ SE } & \multicolumn{2}{|c|}{$95 \% \mathrm{CI}$} & \multirow[b]{2}{*}{$\mathbf{t}$} \\
\hline & & & Lower & Upper & \\
\hline Ostracism & -1.212 & 0.038 & -1.287 & -1.138 & $-31.830^{* * *}$ \\
\hline $\mathrm{CE}$ & 0.108 & 0.039 & 0.033 & 0.184 & $2.82^{* *}$ \\
\hline $\begin{array}{l}\text { Ostracism } \times \\
\mathrm{CE}\end{array}$ & -0.195 & 0.030 & -0.254 & -0.135 & $-6.25^{* * *}$ \\
\hline$R^{2}$ & & & 0.498 & & \\
\hline$F$ & & & 394.834 & & \\
\hline
\end{tabular}

Note: $\mathrm{n}=1200$, Bootstrap sample size $=5000, \mathrm{CE}=$ Consumer Ethnocentrism, $\mathrm{SE}=$

Standard Error, $\mathrm{CI}=$ Confidence Interval. All variables are standardized. ${ }^{*} \mathrm{p}<.05,{ }^{* *} \mathrm{p}$

$<.01,{ }^{* * *} \mathrm{p}<.001$ 


\section{Table 7}

Result of Simple Slope Analysis

\begin{tabular}{|c|c|c|c|c|c|c|c|}
\hline Moderator levels & & & $95 \%$ & CI & & & \\
\hline Consumer ethnocentrism & $\beta$ & $\mathbf{S E}$ & Lower & Upper & df & $\mathbf{t}$ & $\mathbf{p}$ \\
\hline Low (Mean-1·SD) & -1.02 & 0.0516 & -1.12 & -0.916 & 1195 & -19.7 & $<.001$ \\
\hline Mean & -1.21 & 0.0381 & -1.29 & -1.137 & 1195 & -31.8 & $<.001$ \\
\hline High $($ Mean $+1 \cdot S D)$ & -1.41 & 0.0456 & -1.50 & -1.318 & 1195 & -30.9 & $<.001$ \\
\hline
\end{tabular}

Note: $\mathrm{n}=1200, \mathrm{CI}=$ Confidence interval. Table 6 shows the effect of the predictor

(Ostracism) on the dependent variable (Self-esteem) at different levels of the moderator (Consumer ethnocentrism) 


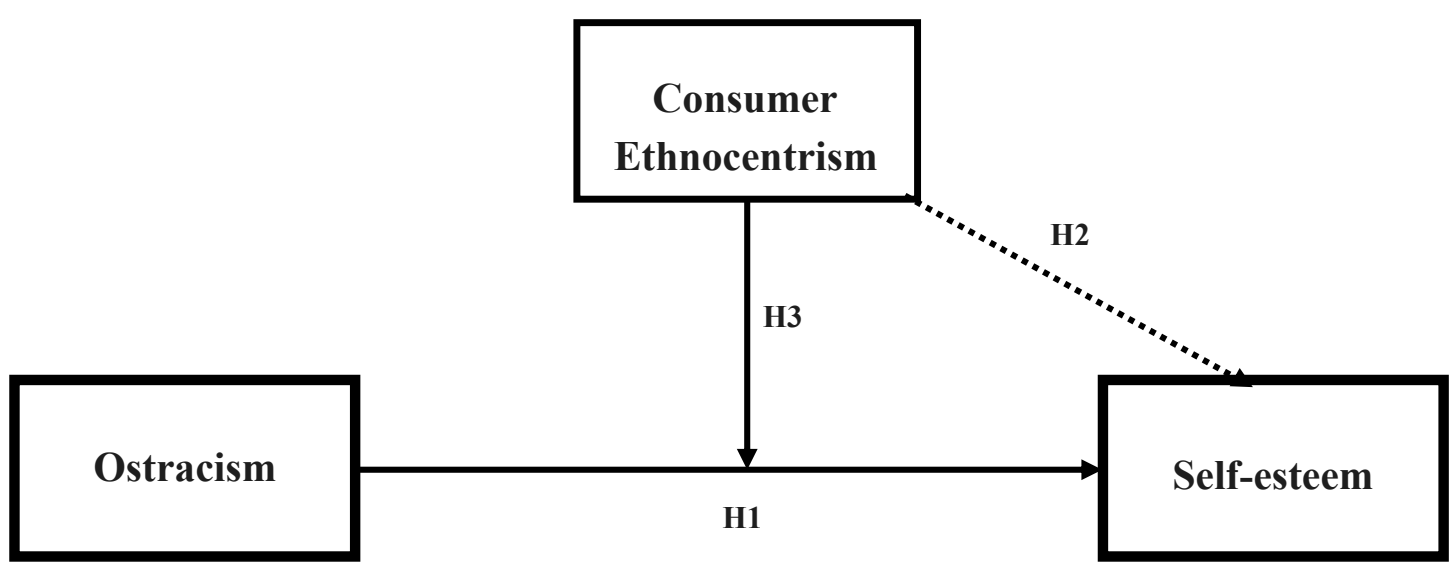

Figure 1. Conceptual Model of the Current Study. H1: Ostracism is negatively correlated with Self-esteem; H2: Consumer ethnocentrism is positively correlated with self-esteem, H3: Consumer Ethnocentrism is moderator on the effects of ostracism on self-esteem. 


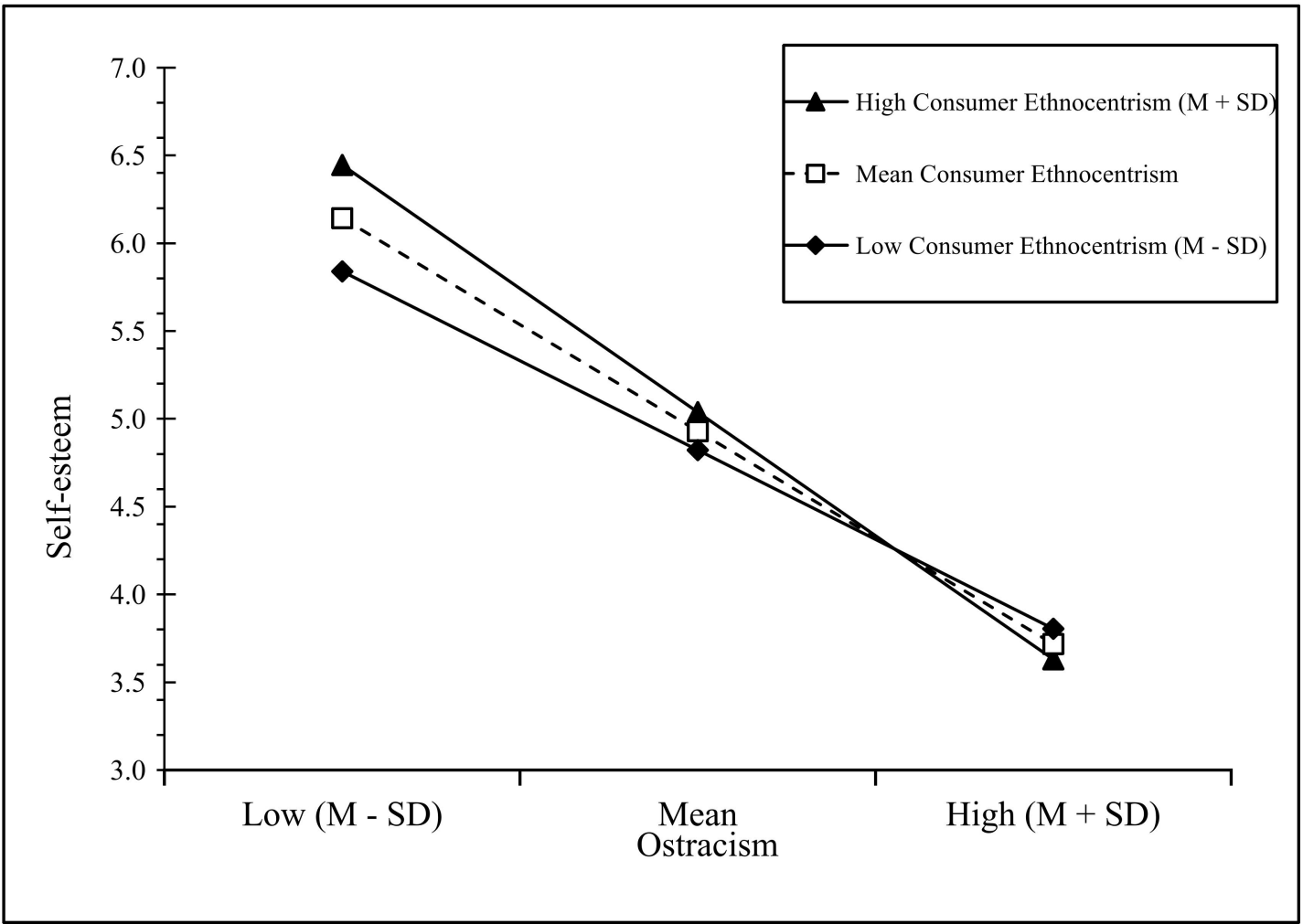

Figure 2. The effect of Ostracism on Self-esteem at Different Levels of Consumer Ethnocentrism. 